\title{
A TRANSFERÊNCIA E O DESEJO DO ANALISTA NO CASO DO HOMEM DOS RATOS
}

\section{JULIANA BARTIJOTTOO}

\section{Juliana Bartijotto}

Universidade de São Paulo (USP), doutoranda na Faculdade de Filosofia, Ciências e Letras, Ribeirão Preto/SP, Brasil.
RESUMO: Este artigo aborda o conceito de transferência relativo ao caso do Homem dos Ratos, texto escrito por Freud em 1909. O objetivo principal foi expor o funcionamento da transferência, conceito formalizado por Freud e, também, o desejo do analista articulado ao objeto $a$, noções teóricas cruciais para a psicanálise lacaniana. Para isso, foi realizado um retorno aos comentários dos autores sobre a estrutura obsessiva, seus sintomas e sua fantasia. Desse modo, o texto foi construído a partir da passagem da lógica fálica à noção de objeto $a$, um conceito topológico indispensável na direção do tratamento psicanalítico.

Palavras-chave: neurose obsessiva; transferência; desejo do analista; objeto.

\begin{abstract}
The transference and the desire of the analyst in the case of Rat Man. The article discusses the concept of transference concerning the case of Rat Man, written by Freud in 1909. The principal objective was to expose the operation of the transference, concept formalized by Freud, as well as the desire of the analyst and the object $a$, theoretical notions crucial to Lacanian psychoanalysis. For this, it was done a review of the comments of the authors about the obsessive structure, its symptoms and your fantasy. Thereby, this article was constructed from the passage of the phallic logic to the notion of the object $a$, a topological concept indispensable in the direction of the psychoanalytic treatment.
\end{abstract}

Keywords: obsessive neurosis; transference; desire of the analyst; object.

DOI - http://dx.doi.org/10.1590/1809-44142018001009 


\section{INTRODUÇÃO}

O caso do Homem dos Ratos, escrito por Freud em 1909, é um clássico do campo da neurose obsessiva. Esse artigo aborda um retorno a esse texto e aos comentários de Lacan, ao longo de sua obra, pertinentes à neurose obsessiva. $O$ objetivo foi revelar o funcionamento da transferência e do desejo do analista articulado à noção de objeto $a$, noções indispensáveis para a condução de qualquer caso clínico. Para isso, foram levantados alguns aspectos importantes da estrutura obsessiva, tais como sintomas, ideias obsessivas, atos compulsivos e a composição da fantasia.

Para Freud (1912/1996), a transferência é a atualização da realidade do inconsciente; é uma repetição em ato. Trata-se de um "clichê estereotípico", isto é, atos constantemente repetidos que determinam o sujeito na escolha dos objetos amorosos. Esses impulsos determinam de modo inconsciente o curso da "vida erótica" do sujeito, além de apontar para o desejo incestuoso. Desse modo, a transferência surge como a resistência mais poderosa ao tratamento.

Na clínica psicanalítica, parte da pulsão do analisante volta-se para a figura do analista, ou seja, o paciente inclui o analista em uma das séries psíquicas formadas pela sua fantasia inconsciente. Podemos dizer que a fantasia do paciente se liga a um traço específico do analista, um significante qualquer (Sq), estabelecendo, assim, uma relação com a imago paterna, materna, fraterna por meio da figura do analista.

Nesse sentido, a transferência, ao mesmo tempo em que é imprescindível para uma análise, é o que pode emperrá-la, caso o psicanalista não opere a partir do desejo do analista, quer dizer, momento em que faz semblante de objeto $a$, causa de desejo, conceitos explicados adiante. Lacan (1963-64/2008) afirma que a transferência é um fenômeno que inclui o sujeito, o outro, o Outro e o objeto, e está vinculado à demanda de amor; por isso, um fenômeno peculiar da neurose.

O analista, com sua presença, oferece uma imagem e uma voz ao analisante, a fim de possibilitar a reedição da cena fantasmática para ele. A transferência possibilita a articulação do saber inconsciente e o deslizamento da cadeia de significantes, definido por Lacan (1963-64/2008) como Sujeito suposto Saber (SsS). Esse conceito é o pivô da análise e está relacionado ao circuito pulsional. Esse processo ocorre na relação entre o sujeito, o Outro e o objeto (não entre pessoas), e seu movimento é circular. E, por ser circular, é dissimétrico.

O presente artigo está dividido em três partes. Primeiro, houve um retorno ao caso do Homem dos Ratos, pois, na psicanálise, é a experiência que sustenta a teoria. Em um segundo momento, foi realizado um levantamento dos aspectos teóricos ao articular com algumas passagens do caso. Por fim, algumas considerações finais, que são conclusões provisórias, pois um texto nunca está completamente finalizado. Sempre resta uma parte não escrita, sendo essa que constitui a causa da pesquisa em psicanálise.

\section{HOMEM DOS RATOS: UMA NEUROSE OBSESSIVA}

Um jovem de formação universitária queixava-se de obsessões que tinha desde a infância, intensificadas nos últimos quatro anos. Tratava-se de medos de que algo pudesse acontecer a duas pessoas que ele amava: seu pai e uma dama. Além disso, estava consciente de impulsos compulsivos como cortar a garganta com uma lâmina e a criação de proibições, aparentemente, sem lógica. Perdeu anos com esses pensamentos e já havia realizado vários tratamentos. O paciente já sabia algo sobre a teoria da sexualidade de Freud, e, também, leu A psicopatologia da vida cotidiana, que o fez lembrar-se de seus "esforços de pensamento", quando se deparou com as associações verbais. Aliás, foi por meio dessa leitura que decidiu procurá-lo (FREUD, 1909/1996). Trata-se do início da transferência com o analista.

Quando criança, o paciente viu uma de suas governantas nua. Esse episódio provocou-Ihe o desejo de olhar o corpo feminino nu. Certa vez, ouviu a mesma governanta dizer que ele era desajeitado, seguramente iria falhar. Desde então, o desejo de olhar uma mulher nua (pulsão escópica) sempre acompanhava um afeto 
aflitivo: "Se tenho desejo de ver uma mulher despida, meu pai fatalmente deverá morrer". Uma pulsão erótica contra a qual lutava, um desejo que se tornou uma ideia compulsiva, mas que culminou em uma masturbação em desafio a seu pai, pois realizava tal ato após estudar, a fim de agradá-lo (FREUD, 1909/1996).

O grande medo obsessivo eclodiu depois que se deparou com um capitão que gostava de crueldade e defendia o castigo corporal. Isso se deve a uma viagem em que perdeu seu pince-nez. Nessa mesma viagem, sentou entre dois oficiais; um deles the relatou o teor de um artigo de crueldade que havia lido. Nesse momento, o paciente pediu para Freud (1909/1996) poupá-lo de contar-lhe os detalhes, mas o analista disse que não tinha gosto por crueldade, e certamente não tinha desejo de atormentá-lo. Portanto, o analista saiu do lugar em que foi convocado pelo analisante: um manejo transferencial. Para Freud (1909/1996), não querer falar trata-se de resistência. Ele explicou ao paciente esse conceito teórico. Disse, também, que faria esforços para descobrir o significado do seu sintoma, mas que isso só seria possível se ele lhe fornecesse as pistas.

Os pensamentos alheios e repulsivos do paciente emergiam quando ouvia o capitão falar sobre castigos. Nas palavras do paciente: "Não, isso não... criminoso foi amarrado (...) um vaso foi virado sobre suas nádegas (...) alguns ratos foram colocados dentro dele... e eles..." - e de novo se levantou e mostrava todo sinal de horror e resistência - "cavaram caminho no...", o analista completou, "no ânus". O paciente continuou: "naquele momento atravessou minha mente, como um relâmpago, a ideia de que isso estava acontecendo a uma pessoa que me era muito cara", a dama a quem admirava (FREUD, 1909/1996, p. 150). Na tentativa de evitar essa ideia de castigo à dama, vinha o mesmo castigo aplicado ao pai (já falecido). Conjuntamente, aparecia a ideia da sanção: "não devia devolver o dinheiro senão aquilo iria acontecer" (ibidem, p. 151).

O paciente estava atormentado pelo seu próprio juramento e, certa vez, chamou Freud (1909/1996) de capitão, um indício da transferência. Ele não conseguiu cumprir um juramento, achando-se um covarde e desrespeitando sua própria promessa. Por outro lado, achava covardia realizar o juramento apenas para se livrar de suas obsessões. O próprio paciente sabia que sua promessa era fundada em um equívoco, mas fadada a ser um tormento para ele. No entanto, o autor percebeu que não foi uma boa estratégia fazer a correção do equívoco, pois seu comportamento se tornou mais sem sentido e ininteligível do que antes.

Em determinado momento, começou a tratar-se como criminoso, como se ele tivesse matado o pai. Pautado nisso, Freud (1909/1996) descreve o funcionamento do afeto e do conteúdo ideativo, ou seja, nesse caso, o afeto não justifica o sentimento de culpa, pois este é pertencente ao conteúdo fantasmático inconsciente. O conteúdo ideativo conhecido só entrou em sua real posição por causa de uma falsa conexão. O manejo do analista provocou dúvida no paciente, não acreditava que a autocensura e o sentimento de culpa podiam ter efeitos terapêuticos.

Freud (1909/1996) também explicou sobre a divisão (Spaltung) entre um eu moral (consciente) e um eu mau (inconsciente). Alegou que o inconsciente é o infantil e o recalcado, sendo o responsável pelos pensamentos involuntários. Depois de tais explicações, o paciente lembrou que, na infância, tinha realizado vários atos que, provavelmente, originavam-se do eu mau. Em seguida, ele expressou dúvida em relação à possibilidade de modificar algo que já possuía há longo tempo. Na sequência, ele supôs que devia contar mais sobre a infância.

Os pensamentos em relação à morte do pai o surpreenderam, pois evocaram um medo e um desejo ao mesmo tempo. Freud afirmou que um amor intenso era a precondição necessária do ódio recalcado, ou seja, o amor está vinculado à raiva. O autor faz analogia às palavras de Brutus a Júlio César (Shakespeare): “Como César me amou, eu choro por ele; como foi afortunado; eu me regozijo com isso; como foi valoroso, eu o honro; mas, como foi ambicioso, eu o matei" (FREUD, 1909/1996, p. 160).

O autor marcou, também, a repetição do pensamento da morte do pai e o desejo inconsciente de matálo. Ao escutar essa interpretação, o paciente tornou-se agitado e incrédulo, pois não se tratava de objeto de desejo e, sim, de objeto de medo. Assim, o paciente duvidava do sentimento recalcado em relação ao desejo 
de que seu pai morresse. $O$ analista insistia nas explicações teóricas, pois se tratava da (re)vivência de uma situação antiga em que seu pai era uma interferência na relação dele com a mãe (atualização edípica).

O paciente, em virtude de seu desejo inconsciente, tinha sentimento de culpa; achava-se um criminoso por ter esse desejo, assim, autopunia-se. O efeito desse conflito foram criações das ideias e atos obsessivos. Freud (1909/1996) afirmava que o sentimento de morte pelo pai era a principal fonte da intensidade de sua doença e os sintomas eram formações do inconsciente, assim como os sonhos que têm uma aparência de não possuírem motivo ou significação.

Os pensamentos a respeito da morte de seu pai ocorriam desde que era criança, e Freud (1909/1996) o relacionava à masturbação na infância. Provavelmente, teve na infância uma/um proibição/castigo dos pais em relação a esse ato. $O$ paciente disse que sua mãe repetidamente lhe descrevia acontecimentos dessa ordem. O analista apontou ainda ocasiões que tinham em comum uma proibição e o desafio de uma ordem. Os próprios pacientes, afirma o autor, expressavam que seus sintomas eram derivados da masturbação infantil. O paciente logo se lembrou da cena em que o pai lhe bateu, pois mordeu a babá e, com raiva, respondeu ao pai com os significantes: lâmpada, toalha, prato etc. O pai disse: "Esse menino vai ser um grande homem ou vai ser um grande criminoso". A partir dessa época, foi tomado por um medo da violência da sua própria raiva.

A mãe do paciente era de uma família rica e seu pai, ao casar-se com ela, adquiriu uma posição confortável. O paciente soube que seu pai, antes de conhecer sua mãe, cortejara uma humilde jovem sem recursos. Os pais queriam que ele se casasse com a filha de um primo da mãe, uma relação de negócios. Freud (1909/1996) disse que esse plano familiar desencadeou o conflito que o deixou doente: ou casava-se com a jovem rica, como seu pai, ou ficava com a jovem pobre que amava. Ele resolveu o conflito permanecendo doente, assim evitava a tarefa de resolvê-lo na vida real. Para não enfrentar a perda, o obsessivo tende a não escolher, pois tenta realizar uma conexão que desafia a lógica entre os antagonistas, isto é, deseja escolher duas opções contrárias: casar-se com a jovem rica e com a pobre.

O paciente não aceitou de bom grado a explicação de Freud sobre a causa de seus sintomas obsessivos. Ele não imaginava que o plano do casamento fosse desencadeador de uma série de ideias obsessivas e atos compulsivos. Logo após esse episódio, emergiu uma fantasia de transferência: ele vira uma moça na escada do consultório do analista e supôs ser filha dele, emergindo a ideia de que Freud desejava tornar-se sogro do paciente. Depois dessa sessão, o paciente teve um sonho com essa jovem que, em vez de olhos, tinha estrumes. A interpretação do analista se deu da seguinte forma: "Ele se casava com minha filha, não por causa de seus belos olhos, mas sim pelo dinheiro" (FREUD, 1909/1996, p. 175); o estrume equivalia ao dinheiro. Mesmo assim, o paciente estava cego quanto à analogia feita entre a transferência presente e os acontecimentos passados.

O pai do analisante era jogador (rato de jogo); perdia muito dinheiro nos jogos de cartas e adquiriu uma grande dívida. Quando o paciente ouviu dizer que ele devia ao tenente, teve alusão a essa dívida não liquidada do pai. O paciente associou a ideia de punição por meio de ratos que evocaram uma série de significados simbólicos, articulados ao erotismo anal e ao dinheiro. Desse modo, o analista pautava sua escuta na associação entre as palavras: Ratten (ratos), Raten (prestações), heiraten (casar) e moeda-rato (FREUD, 1909/1996).

Certa vez, ao pagar Freud, o paciente disse: "Tantos ratos, tantos florins" (FREUD, 1909/1996, p. 187). Associou, também, com o fato dos ratos serem portadores de doenças contagiosas, sendo que o próprio pênis é portador de infecção sifilítica; logo, considerava o rato como um órgão sexual masculino. Desse modo, o pênis foi comparado a um verme. Emergiu na fala do paciente, a mulher-rato do Pequeno Eyolf, isso o levou a outro significado, o de crianças. O paciente lembrou-se de ter visto um rato ao visitar o túmulo de seu pai, que lhe fez ter outra ideia: tinha saído do túmulo porque tinha devorado um pedaço do cadáver. O rato possui dentes afiados, rói e morde. Ele próprio tinha sido um sujeitinho asqueroso e sujo, pronto a morder as pessoas 
quando enfurecido, sendo que foi punido pelo ato cometido. Assim, viu no rato sua própria imagem - ratos eram crianças.

O paciente, quando ouviu o capitão contar sobre a punição com ratos, chocou-se com a crueldade. Logo verificou uma conexão inconsciente com a cena oriunda da infância, na qual tinha mordido alguém - o capitão tornou-se substituto de seu pai -, surgindo uma ideia de que devia acontecer algo ruim a alguém de quem ele gostava. Mas sabia que estava equivocado. Um pensamento surgiu como resposta à dívida: "Reembolsarei o dinheiro ao tenente A quando meu pai e a dama tiverem filhos" (FREUD, 1909/1996, p. 190), mas era algo impossível de acontecer, já que o pai era falecido.

Pelo caminho da transferência, foi capaz de se convencer da relação ambígua que mantém com o pai e com a dama. Suas fantasias e sonhos atingiram um ponto em que agredia verbalmente o analista e seus familiares, e perguntava-Ihe como podia aceitá-lo como paciente. Freud (1909/1996) afirma que as duas falas do capitão (sobre o rato) e seu pedido ao paciente que pagasse ao tenente $A$ desempenharam um efeito sintomático e reações violentamente patológicas. Tratava-se de uma identificação com o pai que exercia serviços militares e uma alusão à dívida não liquidada de seu pai. Além disso, toda fantasia de prostituta remetera sempre à sua mãe. Quando tinha doze anos, um amigo disse que sua mãe se comportava como prostituta, e, também, quando a mãe penteava os cabelos, chamava-os de rabos de rato. Desse modo, a ideia de punição com ratos evocara um conjunto de recordações com significações simbólicas.

As ideias obsessivas se definem por autocensuras transformadas que insurgem do recalque e se referem a algum ato sexual praticado na infância. A neurose obsessiva é uma estrutura que tem a natureza de uma conciliação entre ideias recalcadas e ideias repressoras. Os efeitos dessa estruturação podem ter como características: desejos, tentações, impulsos, reflexões, dúvidas, rituais, ordem e proibições. Os pacientes esforçam-se por amenizar o conteúdo inaceitável pelo inconsciente, assim eles destituem de afeto tais conteúdos, deslocando-os para outras ideias (FREUD, 1909/1996).

A ideia obsessiva mostra em sua deformação, a partir de seu teor original, vestígios da luta defensiva primária. Sua deformação permite que ela persista. Isso equivale ao funcionamento dos sonhos, que nada mais são do que a tentativa de conciliação entre duas ideias antagônicas ou ideias insuportáveis para o eu. As ideias obsessivas com os ratos cessaram; cabe ressaltar que nem todas as obsessões foram complicadas de resolver como a dos ratos.

No próximo item, foi abordado o manejo da transferência, quando se trata da lógica fálica, do objeto pulsional e do complexo edípico, bem como a direção do tratamento sustentada pelo desejo do analista que se dá, especificamente, a partir do objeto $a$.

\section{O MANEJO TRANSFERENCIAL E O DESEJO DO ANALISTA: DO FALO AO OBJETO $A$}

Lacan (1957/1996) servia-se da lógica fálica e da teoria do Édipo para diagnosticar uma estrutura clínica. Mas, depois da invenção do objeto $a$, o autor coloca-o como central na suposição diagnóstica e na direção do tratamento. Portanto, podemos dizer que há três noções de objeto na psicanálise: o objeto $a$ como causa de desejo, o falo como um significante privilegiado que representa a falta $(-\phi)$ e os pulsionais, que entram na série dos objetos perdidos (LACAN, 1962-63/2005).

A invenção do objeto a traz novidades para a clínica, mas não implica a exclusão da lógica fálica no manejo da transferência; representa apenas um passo adiante na condução dos casos. O objeto $a$ é uma noção topológica que indicia um vazio e possui uma função específica: causar o desejo. Ao passo que o pulsional é aquele que se perde e manifesta-se de quatros formas: supereu (voz), escópica (olhar), oral (seio) e a anal (fezes). O sujeito cede esses objetos ao Outro. Por isso, em uma análise, é preciso possibilitar a passagem de um objeto que se perde ao objeto impossível de apreender.

Pautado na lógica fálica, Lacan (1957-58/1999) admite que o desejo do ser falante, especificamente, da neurose, passa pelo desejo do Outro. A fantasia é uma tentativa de resposta a esse desejo, mas sempre 
fundada no insucesso. Ela possui um papel enigmático na neurose, assim, a questão "O que o Outro quer de mim?" persiste ao longo da vida do sujeito. Isso equivale à castração simbólica que coloca em jogo a função narcísica na tentativa de dar conta da falta. Assim, a imagem especular tem função polivalente, não neutralizada e opera no plano da relação erótica de modo agressivo.

A relação do obsessivo com a imagem do outro - representado pela sigla i(a) - situa-se no nível de uma experiência primitiva do circuito da demanda, momento em que o sujeito dirige-se ao Outro para satisfação de suas necessidades. Portanto, o campo da realização do desejo se constitui, inicialmente, no campo do Outro. Importante ressaltar que a função da fantasia (\$<>a) situa-se no ponto homólogo ao desejo; ela está aprisionada numa dimensão imaginária e numa dimensão da cadeia de significantes (LACAN, idem).

Para o neurótico, o desejo é paradoxal: quer e não quer realizá-lo ao mesmo tempo; para ele, é necessário manter a falta para não se fixar no lugar de objeto do Outro. O obsessivo fala para o analista sobre seus empecilhos, inibições, bloqueios, medos, dúvida e proibições, mas não fala de forma clara e articulada sobre sua fantasia. Essa vem nas entrelinhas, nas posições diante dos outros e do próprio analista (LACAN, idem). Para isso aparecer, são necessárias intervenções analíticas: interpretações (e não sugestões), marcações, pontuações, torções, cortes etc. A fantasia, na realidade, é construída de modo articulado no decorrer do processo analítico. Apesar de não aparecer, a fantasia na vida do neurótico obsessivo é invasiva, predominante, absorvente e ocupa grande parte de sua vida psíquica.

O desejo no obsessivo é tomado como proibido, mas não significa um desejo sufocado. A proibição está ali para sustentar o desejo, mas, para que ele se sustente, é preciso que se apresente. O modo como faz é complexo, desembocando repetidas vezes em agressividade (sadismo). A emergência de seu desejo é percebida como um medo de retaliação, e, quando o desejo vai longe demais, torna-o agressivo ou pende para um novo desaparecimento. Existe, portanto, a tendência em reduzir o desejo à demanda. Assim, para mortificar o desejo, o obsessivo escolhe uma saída oblativa, isto é, sacrifica-se a si mesmo para satisfazer o Outro (LACAN, 1957-58/1999). O lugar do rival, para o obsessivo, é um lugar fictício; seu adversário é criado por ele mesmo, por isso, pautado na sua fantasia.

O neurótico obsessivo inscreve o campo da dialética anal como privilegiado, o estádio pulsional em que se instaura a demanda do Outro, o verdadeiro campo da oblatividade. O obsessivo faz tudo para o Outro, entretanto, ele nunca faz o bastante para que esse outro se mantenha na existência. A fase anal se caracteriza pelo seguinte: o sujeito só satisfaz uma necessidade tendo como referência a demanda do Outro. Existe uma fixação no tempo anal, porque foi nesse momento ensinado a reter a necessidade para fundir a satisfação e a demanda do Outro. De tal modo, o desejo é simbolizado por uma situação em que o próprio desejo é suprimido. O desejo, literalmente, vai à merda, diz Lacan (1960-61/1992); vai embora pelo buraco da descarga.

Em Homem dos Ratos, existe um ponto de identificação entre ele enquanto criança e o rato que vem substituir o objeto excrementício, mas há uma inversão, pois em vez de sair pelo ânus, como as fezes, o rato entra. Exatamente no momento em que ele morde a governanta, emerge na fala do pai o enunciado: "Vai ser um grande homem ou um criminoso". Como ele responde? Como um criminoso na fantasia que precisa ser punido, em virtude do desejo de matar o Pai, mas, no plano da realidade, manifesta-se como um grande covarde.

No manejo da transferência da neurose obsessiva, a compreensão da demanda deve ir devagar e não se deve ceder a nenhuma desculpabilização. O que o paciente diz sempre está articulado à fantasia e não à realidade. O fundamental em uma análise é o dizer do analisante; então, caso ele se ache um criminoso, o analista não deve nem corrigi-lo e nem dizer que nada fez. Freud, quando tentou corrigir o equívoco do Homem dos Ratos em relação à promessa de pagamento, como efeito, ele se tornou mais agitado e fazia coisas mais ininteligíveis. A armadilha é oferecer uma interpretação inexata ao sujeito ou reveladora demais. O que realmente o sujeito precisa é daquilo que ele significa metonimicamente e que não é localizável em 
ponto nenhum da fala, mas que pode ser marcada pelo analista na cadeia de significantes, aquela que está na superfície da fala do analisante.

Lacan (1960-61/1992, p. 312-313) escreve a fórmula da fantasia do obsessivo do seguinte modo: $A<>\varphi$ $\left(a, a^{\prime}, a^{\prime \prime}, a^{\prime \prime \prime}\right.$...). Lê-se: Grande Outro barrado frente à disjunção e junção do falo simbólico que resulta na degradação do Outro em vários pequenos outros. Quando se fala em transferência, o analista é incluído nessa fórmula fantasmática e passa a fazer parte da cena, completando o sintoma do paciente. Essa fórmula escreve a relação do obsessivo com o objeto fálico (o imaginário e o simbólico). Nessa articulação, o objeto $a$ não é considerado.

Freud entra na série dos objetos degradados pelo Homem dos Ratos - o outro imaginário - o alvo da agressividade do analisante. Nesse contexto, privilegia-se uma dimensão narcísica em que o sujeito se depara com o furo na imagem (- $\phi)$ que tenta preencher por meio da fantasia; os ratos que entram pelo ânus tamponam imaginariamente o buraco constitutivo. Os objetos são, para ele, colocados em função de certas equivalências eróticas que podem ser notadas pelo falo, que é uma unidade de medida.

A cena do rato instaura horror ao mesmo tempo em que um modo de gozo é captado. Importante salientar que o rato prossegue sua corrida de forma multiplicada, em toda a economia dessas trocas singulares, dessas substituições, desses deslocamentos que fazem parte dos sintomas do obsessivo (LACAN, 1960-61/1992, p. 314). Por isso, a partir do significante rato, monta-se uma série articulada: Ratten (ratos), Raten (prestações), Spielratte (dívida de jogo), heiraten (casar), mulher-rato do pequeno Eyolf (equivalência entre criança e rato). Freud foi perspicaz ao pinçar essa série significante no dizer do paciente.

A instauração da transferência se manifesta no pagamento dos honorários, quando o paciente diz "Tantos ratos, tantos florins", ou seja, ratos equivalem à moeda de troca. Isso não passa de uma ilustração particular da correspondência de todos os objetos que é uma espécie de mercado, do metabolismo dos objetos nos sintomas. O rato simboliza o pequeno $\phi$ na medida em que ele é, de certa forma, uma multiplicação do falo simbólico. Assim, o Homem dos Ratos degrada o Outro barrado numa série de pequenos outros, a fim de apagar a barra no Outro e nele.

A fantasia sádica com os ratos eclode quando ouve o capitão narrar o castigo com os ratos, porque esse significante estava, não de forma articulada, inscrito em sua cadeia de significantes, como traços mnêmicos na linguagem freudiana ou traços de gozo na linguagem lacaniana. Contudo, como é possível que as coisas sejam ao mesmo tempo tão ditas e tão desconhecidas? Essa é a função do recalque (Verneinung). Por mais confessada que seja pelo sujeito, ele não a reconhece sem a ajuda do analista. Sem o subsídio de Freud, o Homem dos Ratos não se reconheceria naquilo que fala e nem seria reconhecível. Assim, pode-se comprovar que ser sujeito é algo diferente de ser um olhar diante de outro olhar. Ser sujeito é ter seu lugar na fala do Outro barrado (LACAN, 1960-61/1992). Oferecer significado à função fálica faz o sujeito desvanecer, não se reconhecer mais. Na falha desse reconhecimento, produz-se uma miragem narcísica que angustia o sujeito. Essa alienação ao falicismo se manifesta de modo visível no Homem dos Ratos, por exemplo, naquilo que se chama suas dificuldades de pensamento.

Na transferência, o sujeito atualiza seus temas inconscientes, mas isso não ocorre sem a angústia. Para Lacan (1954/2008), os traços do complexo familiar do Homem dos Ratos se especificam pela tentativa de união dos pais. O roteiro do pai se repete no do filho, ou seja, o impasse entre casar com a moça rica ou com a moça pobre. O pai escolhe casar-se com a moça rica, mas, mesmo assim, se endivida. Esses complexos se manifestam, de um lado, pela dívida do pai e, de outro, pela substituição da mulher pobre pela rica. Portanto, há uma dupla dívida: a castração do pai e a dívida social nunca resolvida. A dívida está situada em dois planos, mas existe uma impossibilidade de fazer esses dois se encontrarem. Ao tentar fazer um recobrir o outro, eclode todo o drama do Homem dos Ratos, isto é, uma operação circular, nunca satisfatória e que nunca fecha o seu ciclo.

O que acontece com o Homem dos Ratos no tratamento com Freud? Conforme afirma Lacan: 
Num primeiro tempo, Freud substitui muito diretamente, nas suas relações afetivas, um amigo que desempenhava um papel de guia, conselheiro, protetor, tutor, tranquilizador, que depois de ouvir a confidência de suas obsessões e angústias Ihe dizia regularmente: 'você nunca fez o mal que acredita ter feito, você não é culpado, não se preocupe'. Freud é, portanto, posto no lugar do amigo. E muito rapidamente desencadeiam-se fantasias agressivas. Elas não estão unicamente ligadas, longe disso, à substituição do pai por Freud, como a interpretação do próprio Freud, tende incessantemente manifestar, mas antes, como na fantasia, à substituição do amigo pelo dito personagem da mulher rica. (LACAN, $(1954 / 2008$, p. 27)

Por isso, na sequência,

[...] o sujeito se põe a imaginar que Freud deseja nada menos do que Ihe dar a própria filha, da qual faz fantasticamente um personagem dotado de todos os bens da terra e que ele representa sob a forma bastante peculiar de um personagem com olhos de estrume. Trata-se, portanto, da substituição do personagem Freud por um personagem ambíguo, simultaneamente protetor e maléfico, cujos olhos esquisitos indicam bem, por outro lado, a relação narcisista do sujeito. (Idem, p. 28)

No entanto, Freud deixa o analisante fantasiar e apenas testemunha seu delírio, possibilitando, assim, que ele fale. Nesse momento, manifesta-se uma divisão interna que faz do sujeito a testemunha alienada dos atos de seu próprio eu, além de revelar um gozo na própria fantasia montada a partir de seus significantes e do complexo edípico.

Ao dar um passo além da lógica fálica na direção do tratamento, segue-se com a operação da análise a partir do desejo do analista e do objeto a. No Seminário 10: a angústia, Lacan formaliza a noção de objeto $a$, um objeto topológico causa de desejo, sendo este "a única via pela qual o desejo pode revelar-nos de que modo teremos que reconhecer em nós [os analistas] o objeto $a^{\prime \prime}$ (LACAN, 1962-63/2005, p. 266). Cabe ressaltar que esse objeto está situado no campo do Outro; isso é a possibilidade de transferência.

O desejo no obsessivo é tomado como imperativo, por isso, facilmente se torna compulsivo, isto é, passa para a outra extremidade, a do gozo. O sujeito obsessivo procura incessantemente um objeto que não existe, o que acha é o objeto derradeiro que não o satisfaz. Ele permanece nessa busca infinita, com seus tempos de suspensão, seus caminhos errados, suas pistas falsas e suas derivações laterais. Isso pode se manifestar no acting out e no sintoma da dúvida que marcam, para o sujeito, o valor de todos os objetos substitutos. Todavia, ele se perde nesse caminho ao criar um embaraço, um impedimento daquilo que é possível e toma o impossível como impotência. Nesse sentido, o obsessivo se defende do desejo a todo custo, mas, ao se defender, a falta falta, o que faz surgir a angústia. $O$ analista não responde à angústia, mas intervém a partir do objeto $a$, não um objeto suposto perdido, mas, sim, aquele que "não cessa de não se escrever"; esse é o ponto da impossibilidade (LACAN, 1972-73/1985, p. 127).

Todo neurótico gostaria que a união genital fosse uma possibilidade, mas não há nenhum vestígio de que essa união seja possível, ou seja, não há relação sexual. Não há dom, a não ser ali na identificação com o objeto pulsional; no genital, a hiância impera. O plano anal sustenta todo o terreno em que o desejo e o gozo do obsessivo são jogados; nesse campo, manifestam-se seus sintomas, suas sublimações e as possibilidades de funcionamento daquilo que contorna o furo central do desejo. Isso acontece, também, no nível escópico, pois a imagem especular entra numa função análoga à dimensão anal, por serem posições correlatas (LACAN, 1962-63/2005).

Em relação à mulher, o Homem dos Ratos a coloca como um objeto enaltecido e proibido. Quando se trata da mulher, ele nem quer olhar, faz isso ao se impedir de olhar uma mulher nua, senão seu pai morrerá. Porém, o que ele ama é uma imagem sua espelhada no pequeno outro, investido no objeto mais amado e odiado. A manutenção dessa imagem é o que faz o obsessivo angustiar-se e não reconhecer-se no sintoma que ele mesmo produz.

Outra característica do obsessivo é a dúvida que vem para evitar a angústia de castração. Dúvida diante das escolhas que precisa realizar na vida que, consequentemente, geram perdas; e ele sabe disso. Existe uma 
necessidade de obter incertezas em sua vida, e que muitas vezes o paralisam. A dúvida é um método a fim de atrair o sujeito para fora da realidade e isolá-lo do contexto social. Portanto, diante de um impasse, ele o resolve sob a forma de sintomas. Desse modo, foge do seu desejo, obrigando-se a se sacrificar pelo Outro.

A dúvida no obsessivo é uma tentativa de apagar a angústia e não produto dela. O enunciado proferido pelo pai do Homem dos Ratos - "Vai ser um grande homem ou um grande criminoso" - trata-se do vel ${ }^{l}$ da alienação. $O$ "ou", pela lógica dos conjuntos, é um conectivo que indica uma disjunção; nesse caso, ele a toma como exclusiva. A proposição resultante da disjunção exclusiva só será "Verdadeira" se uma das partes for "Falsa" e a outra "Verdadeira", não podendo acontecer "Verdadeira" nos dois casos; caso aconteça, a proposição resultante dessa operação será "Falsa".

Portanto, fazer uma escolha (será um grande homem ou um criminoso) é como chegar a uma bifurcação - ou vou para lá ou para cá -; na escolha de um caminho, perde-se o outro. Mas o neurótico não percebe que possui outro caminho que não seja nenhum dos dois; torna-se alienado a uma proposição que toma como uma lógica em que deve escolher.

Para Lacan (1964-65/2008), caso escolha o ser, o sujeito desaparece, ele escapa e cai no não sentido; caso escolha o sentido, esse vem decepado da parte do não sentido. O sentido emerge no campo do Outro, mas eclipsado pelo desaparecimento do ser induzido pela função do significante. Esse é o processo de alienação do sujeito em relação ao campo do Outro. A segunda operação da alienação é a interseção, constituída pelos elementos que pertencem aos dois conjuntos: sujeito e Outro. É a ocasião em que o sujeito se pergunta "O que Outro quer dizer?". O momento enigmático em que falta a resposta do Outro, somente assim o sujeito emerge. Portanto, o enigma precisa ser mantido.

O Homem dos Ratos aliena-se ao significante criminoso cedido pelo pai, mas não totalmente, pois, na realidade, ele se tornara um grande medroso e covarde. Freud aponta que o criminoso tem relação com o desejo de matar o Pai, mas esquece-se de que o próprio Outro (encarnado na figura do pai) diz que ele será um criminoso ou um grande homem. Essa realidade é apagada na série de significantes do analisante e que poderia ser marcada pelo analista.

O saber é uma forma de dar um nó naquilo que se formula no campo simbólico. Entretanto, o neurótico se vê em um impasse diante dos enunciados proferidos pelo Outro. $\mathrm{O}$ Homem dos Ratos, quando convocado a exercer a função do pai simbólico e a posição de gozo viril na conjunção sexual, supõe que precisa assassinar um pai que nem sequer existe (o pai da horda primitiva que goza de todas as mulheres) para ocupar tal lugar. O obsessivo facilmente recusa ocupar tal função, pois o que importa é a relação do saber com o gozo, e a sua posição tende a ser do escravo em relação ao Outro. Almeja um Mestre que lhe proíba aquilo que deseja, mas que o deixe na interrogação infinita em relação ao saber. O saber, na realidade, é meio de gozo, por isso, goza pelo pensamento.

O intuito da análise é fazer o sujeito perceber que não há ligação sem intervalo entre um significante e outro e, também, que um significante sozinho não faz significação. Portanto, a primeira operação se refere à não reciprocidade e a segunda, à torção no retorno. Nas duas operações, cai-se na falta, mas de modo diferente: a primeira como perda e a outra como causa. O efeito de torção é essencial para integrar a fase de saída da transferência, mas, para isso, é preciso operar com o objeto a causa, sustentado pelo desejo do analista.

Lacan (1962-63/2005, 1964-65/2008), com a noção de objeto $a$, criou condições de manejar a transferência a partir do desejo do analista e de um objeto que é pura falta, impossível de apreender, mas é o que coloca toda a cadeia de significantes em movimento e causa o desejo no sujeito. Sobre a articulação entre a transferência e o desejo do analista, o autor afirma:

\footnotetext{
${ }^{1}$ Apagamento do furo que dá a ilusão de unidade.
} 
[...] se a transferência é o que, da pulsão, desvia a demanda, o desejo do analista é aquilo que traz ali de volta. $\mathrm{E}$, por essa via, ele isola o $a$, põe à maior distância possível do I (ideal) que ele o analista é chamado pelo sujeito a encarnar. (LACAN, 1964-65, p. 264)

O desejo do analista é o que possibilita o psicanalista fazer semblante de objeto $a$ para o analisante. Para isso, o analista precisa abster-se de seu ser no processo analítico, operando com a presença ao fazer semblante de um lugar vazio. No discurso do analista, o agente é o objeto $a$, este que coloca o discurso em movimento, sustentando a transferência. Nesse sentido, Lacan afirma que a posição do analista é "feita substancialmente do objeto $a^{\prime \prime}$ (LACAN, 1970-71/1992, p. 40). Mas ele não é o objeto $a$, por isso, a única possibilidade é fazer semblante dele, um artifício que evoca algo da verdade da ficção da história do sujeito.

Vale lembrar que o semblante não é o mesmo que a identificação. O semblante quer dizer fazer o objeto $a$ operar numa análise, sem sê-lo. Não se trata de verdade ou de mentira. O semblante, numa análise, tem como função anular a oposição entre verdadeiro ou falso; o que importa na análise é a posição do sujeito e de como a fantasia é montada na análise. Para Lacan, o semblante deve ser tomado no sentido do genitivo objetivo, isto é, "como objeto próprio com que se regula a economia do discurso" (LACAN, 1971-72/2009, p. 18).

Essa regulação ocorre devido ao desejo do analista que possibilita a operação da análise a partir do objeto $a$ e não de um objeto perdido. Logo, a posição do analista implica em manter o vazio, operando com a falta e não a tamponando. $O$ analista, por já ter passado pela experiência de uma análise, sabe que não existe proporção exata entre o sujeito e o objeto, por isso, direciona o tratamento a fim de que o analisante apreenda a falta como estrutural.

Observa-se que Freud (1909/1996) não entra com o seu ser na análise do Homem dos Ratos, mas ele opera a partir de um objeto que supõe que um dia esteve lá, o perdido, e não com a falta estrutural propriamente dita. Desse modo, ele supunha que existiria uma verdade última sobre o inconsciente, ao passo que Lacan (1970-71/1992) apontava o inconsciente como um discurso que faz semblante, propício ao jogo de significantes e significações correlato ao funcionamento da linguagem. Desse modo, a verdade do sujeito só pode ser semi-dita, pois sempre resta uma parte que não se escreve no simbólico e que não cessa de causar efeitos, a saber, o objeto $a$.

\section{CONSIDERAÇÕES FINAIS}

A transferência no tratamento psicanalítico não se refere a uma relação interpessoal, mas à relação do sujeito com o Outro/outro e com o objeto. O analista não entra no contexto clínico como sujeito, mas, sim, como Outro barrado inicialmente e, depois, como semblante do objeto a causa de desejo para o analisante. Para que uma análise ocorra, é necessário que o paciente se identifique com um significante qualquer do analista. O analista, quando se retira como sujeito do jogo analítico, possibilita que o inconsciente do analisante se mostre por meio dos mecanismos da repetição e do circuito pulsional. Podemos dizer que isso se refere ao desejo do analista. Para o analista, não se colocar como sujeito traz uma angústia que precisa ser manejada em sua própria análise.

Freud era colocado, algumas vezes, no lugar de Sujeito suposto Saber (SsS). Às vezes, respondia desse lugar, por exemplo, quando oferecia explicações teóricas ao paciente; às vezes, invertia os lugares, deixando o paciente falar sem expor suas curiosidades, pois o verdadeiro SsS, em uma análise, é o inconsciente do analisante.

O modo como Freud conduziu o tratamento, no caso Homem dos Ratos, revela como ele soube manejar a transferência, mas a partir do complexo edípico e da lógica fálica. Por exemplo, no momento em que Freud disse que não era o capitão e que não tinha desejo de crueldade. E o significante a que o paciente se agarrou - a filha de Freud - que nem era a filha dele, o analista não o corrigiu, deixando o analisante dizer sobre suas cenas inconscientes sem apontar se era realidade ou não, pois se tratava de sua realidade psíquica. A cadeia 
significante girava em torno do rato que fora transformado em ratos, os pequenos outros que depuram o Outro barrado, pois era uma neurose.

O desejo do analista é um desejo de que uma análise opere a partir do objeto a e que chegue ao seu fim. $\mathrm{O}$ analista precisa estar advertido de seu lugar na transferência, do funcionamento do sujeito e da falta estrutural. O falo é um significante que representa a falta e o objeto $a$, não é um significante e nem o objeto perdido, mas, sim, uma noção topológica que, a partir do desejo do analista ao fazer semblante dele preserva o vazio e mantém desejo do analisante numa análise. Assim, o desejo do analista pode ser transmitido na experiência analítica. Observa-se que Freud soube marcar as repetições, entrar e sair do lugar convocado pelo paciente. Entretanto, o autor operou a partir da lógica fálica; não foi além, pois era a articulação que possuía naquele momento.

Recebido em: 30 de janeiro de 2016. Aprovado em: 4 de agosto de 2016.

\section{REFERÊNCIAS}

FREUD, S. Notas sobre um caso de neurose obsessiva (1909). Rio de Janeiro: Imago, 1996. (Edição standard brasileira das obras psicológicas completas de Sigmund Freud, 5).

LACAN, J. O mito individual do neurótico (1954). Rio de Janeiro: Zahar, 2008.

. Direção do tratamento e os princípios de seu poder (1957). In: Escritos. (V. Ribeiro, trad.). Rio de Janeiro: Zahar, 1992

Formações do inconsciente (1957-1958). (V. Ribeiro, trad.). 2a. ed. Rio de Janeiro: Zahar, 1999. (O seminário, 5 ).

A subversão do sujeito e dialética do desejo no inconsciente freudiano (1958). In Escritos. (V. Ribeiro, trad.). Rio de Janeiro: Zahar, 1998. seminário, 8).

Transferência (1960-1961). (D. D. Estrada, trad.). 2 ed. Rio de Janeiro: Zahar, 1992. (O 10). A angústia (1962-1963). (V. Ribeiro, trad.). 2a ed. Rio de Janeiro: Zahar, 2005. (O seminário,

Os quatros conceitos fundamentais da psicanálise (1964-1965). (V. Ribeiro, trad.). 2a ed. Rio de Janeiro: Zahar, 2008. (O seminário, 11). seminário, 17).

O avesso da psicanálise (1970-1971). (V. Ribeiro, trad.). 2a ed. Rio de Janeiro: Zahar, 1992. (O De um discurso que não fosse semblante (1971-1972). (V. Ribeiro, trad.). 2a ed. Rio de Janeiro: Zahar, 2009. (O seminário, 18). 20). . Mais, ainda (1972-1972). (M. D. Magno, trad.). 2 ed. Rio de Janeiro: Zahar, 1985. (O seminário,

Juliana Bartijotto

jubartijotto@gmail.com 